\title{
The Potential Development Effect of ASEAN Connectivity: The Case of Riau Corridor
}

\author{
ADIWAN FAHLAN ARITENANG \\ Regional and City Planning, Institut Teknologi Bandung, Jl. Ganesha No.10, Bandung, Indonesia \\ email: a.aritenang@sappk.itb.ac.id
}

\begin{abstract}
The implementation of Masterplan on ASEAN Connectivity (MPAC), especially on transportation and connectivity, includes plan to connect the member countries. This paper examined the issues and potential effects of ASEAN Connectivity in Indonesia. The paper conducted qualitative analysis on literature study, policy content analysis, and interviews allowing detail information on the MPAC implementation in Indonesia. The paper findings are as follows; (i) The lack of MPAC implementation at both ASEAN and Indonesia levels. The ASEAN lacks a designated authority and leadership to carry MPAC forward the masterplan, whilst in Indonesia there is no institution to lead the MPAC delivery. (ii) The important role of a leading institution in Indonesian government is to define and determine the strategic projects with higher value added. The paper concludes that the national government should regulate and lead the MPAC projects to ensure regional-wide connectivity with ASEAN, whilst at the same time integrate local development in Indonesia.
\end{abstract}

Keywords: indonesia, ASEAN connectivity, regional development

\section{Introduction}

The vision of ASEAN Leaders to build an ASEAN Community by 2015 calls for wellconnected ASEAN member countries that will contribute towards a more competitive and resilient ASEAN, as it will bring people, goods, services and capital closer together. Enhanced ASEAN connectivity is essential to achieve the ASEAN community's economic growth aspirations.

The MPAC is considered as a stepping stage on building the connectivity of physical, institutional and people mobility that is crucial to accelerate integrated ASEAN market through the ASEAN Economic Community (AEC) (Tongzon and Cheong, 2014). Considering its strategic geographical location, there will be much to gain from two of ASEAN's flagship transport infrastructure projects, the ASEAN Highway Network (AHN) and the Singapore Kunming Rail Link (SKRL) for Indonesia.

Despite many construction and development plans, the implementation of
MPAC remains to be limited in Indonesia since 2010 to 2015. For instance, in the physical connectivity, the projects are dominantly at the feasibility study (FS) stage including Sunda Straits Bridge (SSB), the SingaporeKunming Rail Link (SKRL) to Surabaya and Roll-On/Roll-Of (RO-RO) development in Indonesia. In the institutional connectivity, Indonesia has generally ratified the protocols; however, the implementation should be monitored. This includes The Facilitation of Inter-State Transport (AFAFIST) and "The Facilitation of Multimodal Transport (AFAMT) that have not been ratified, and The Facilitation of Goods in Transit (AFAFGIT) that has only been six protocols ratified by Indonesia. Whilst the ASEAN Single Shipping Market and ASEAN Single Aviation Market remains at the discussion stage.

Thus, this paper aims to explore issues and potential role of ASEAN Connectivity implementation in Indonesia under the MPAC plans. This paper relies on formal documents such as MPAC, national RPJM (Medium-Term

Received: June 02, 2017, Revision: September 31, 2017, Accepted: December 15, 2017

Print ISSN: 0215-8175; Online ISSN: 2303-2499. DOI: http://dx.doi.org/10.29313/mimbar.v33i2.2590.341-349

Accredited B based on the decree No.040/P/2014, valid on February, 18, 2014 until February, 18, 2019. Indexed by DOAJ, Sinta, IPI 
Development Plan) 2015-2019, and the provincial and municipality RPJM. The paper conducts qualitative analysis on literature study, policy content analysis, and interviews allowing detail information on the MPAC implementation in Indonesia.

The paper is structured as follows: the following section revisits the MPAC, followed by section three which examines MPAC implementation progress and issues in Indonesia. In section four the paper examines the potential of MPAC projects implementation in the Riau corridor. The last section discusses the paper conclusion.

\section{Research Method}

This paper employs two research methodologies. First, the content analysis of various law, regulations, and development paper published by Indonesian government and ASEAN Secretariat. This analysis provides background and current update progress of ASEAN Connectivity in Indonesia. Second, the paper also conducts interviews with many stakeholders in the development of ASEAN Connectivity. This allows in-depth information and analysis from competent and authorized government officials regarding the ASEAN Connectivity. Among stakeholders that were included in this survey were BAPPENAS, Ministry of Trade, Ministry of Transportation, and Ministry of Public Works.

This comprehensive data gathering and analysis ensure the paper provides an accurate analysis of the current situation of MPAC and its potential role to support Indonesia development.

\section{ASEAN Connectivity}

The connectivity has been viewed as an important issue related to global economic growth. The growing countries such as Brazil, Russia, India, China, South Africa (BRICS) economies are suggested to have connectivity related issues including basic access to infrastructure, lack of integration between transport types, and over-dependence on road transport that impinging domestic market access which are likely to accentuate these challenges (Coe, 2014).

In ASEAN, the spirit of MPAC is to achieve integration in the region for all dimensions through physical, institutional, and personal connectivity (Das, 2013) (Fig.1).
The connectivity will not only reduce business transaction cost, time and travel but also connects among cores and between the core and peripheral parts of ASEAN to accelerate growth in the region. As such, the MPAC integrates aims of ASEAN development; first, it aims to consolidate three existing pillars of ASEAN (political-security, economic, and socio-cultural) to achieve the goals of ASEAN Community and second, to coordinate infrastructure system to integrate physical, institutional and people-to-people link within as well as outside the region (Abidin and Rosli, 2013, p. 153).

In the MPAC, there are 125 measures which comprise of 55 physicals, 50 institutional and 20 people-to-people connectivity measures. The assessment of MPAC implementation by the ASEAN Secretariat shows that 96 are due for completion by 2015, nine are due to be completed after 2015, while no specific timeline is given for 20 measures.

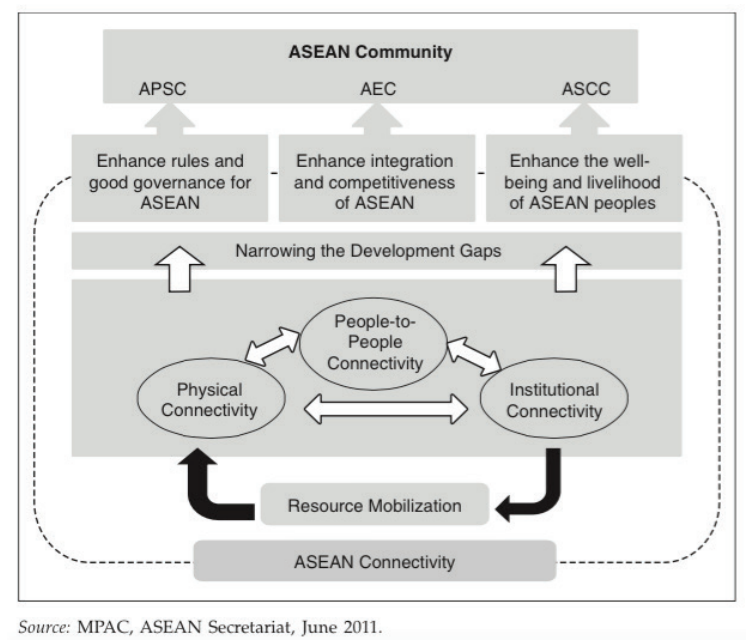

Figure 1. Interaction Between ASEAN Connectivity and ASEAN Community

Until early 2015, 22 measures have been completed, 55 measures have been assessed and likely to be completed by 2015 as substantive progress has been achieved, 19 measures are expected to be completed after 2015 because the implementation plan put in place will go beyond 2015. For MPAC measures due by 2015 and without timelines, it was estimated that $65 \%$ of the measures (or 74 measures) would be completed by 2015. Out of the 74 measures that were or are expected to be completed by 2015, 26 measures are in the physical connectivity dimension, 32 in institutional connectivity, and 16 in people-to-people connectivity as illustrated in Table 2. 
Table 1

Prospective Assessment of Implementing MPAC Measures by 2015

\begin{tabular}{|c|c|c|c|c|}
\hline Assessment & $\begin{array}{c}\text { Measures } \\
\text { by 2015 }\end{array}$ & $\begin{array}{c}\text { Measures } \\
\text { beyond } \\
\mathbf{2 0 1 5}\end{array}$ & $\begin{array}{c}\text { Mea- } \\
\text { sures } \\
\text { without } \\
\text { time- } \\
\text { lines }\end{array}$ & Total \\
\hline Completed & 17 & 0 & 5 & $\mathbf{2 2}$ \\
\hline $\begin{array}{c}\text { Likely to } \\
\text { be Com- } \\
\text { pleted }\end{array}$ & 41 & 1 & 11 & $\mathbf{5 3}$ \\
\hline $\begin{array}{c}\text { Expected } \\
\text { Unlikely to } \\
\text { be Com- } \\
\text { pleted }\end{array}$ & 15 & 4 & 3 & $\mathbf{2 2}$ \\
\hline $\begin{array}{c}\text { Not Yet } \\
\text { Started }\end{array}$ & 3 & 0 & 0 & $\mathbf{3}$ \\
\hline $\begin{array}{c}\text { Not } \\
\text { Prioritised }\end{array}$ & 1 & 2 & 0 & $\mathbf{3}$ \\
\hline Total & $\mathbf{9 6}$ & $\mathbf{9}$ & $\mathbf{2 0}$ & 125 \\
\hline
\end{tabular}

Source: Summary assessment of MPAC implementation as per February 26th 2015

Table 2

Prospective Assessment of MPAC Measures to be completed by 2015 in terms of Physical, Institutional and People-to-People Connectivity

\begin{tabular}{|c|c|c|c|}
\hline $\begin{array}{c}\text { Connectivity } \\
\text { Dimension }\end{array}$ & $\begin{array}{c}\text { Measures } \\
\text { by 2015 }\end{array}$ & $\begin{array}{c}\text { Measures } \\
\text { without } \\
\text { timelines }\end{array}$ & Total \\
\hline $\begin{array}{c}\text { Physical } \\
\text { Connectivity }\end{array}$ & 16 & 10 & $\mathbf{2 6}$ \\
\hline $\begin{array}{c}\text { Institutional } \\
\text { Connectivity }\end{array}$ & 31 & 1 & $\mathbf{3 2}$ \\
\hline $\begin{array}{c}\text { People- } \\
\text { to-People } \\
\text { Connectivity }\end{array}$ & 11 & 5 & $\mathbf{1 6}$ \\
\hline Total & 58 & 16 & $\mathbf{7 4}$ \\
\hline
\end{tabular}

Source: Summary assessment of MPAC implementation as per February $26^{\text {th }} 2015$

The following key action lines have been or are expected to be achieved in the 3 dimensions of physical, institutional, and people-to-people connectivity. Physical Connectivity: The ASEAN Highway Network (AHN) is progressing with sections which are still being upgraded to "Class III" roads within ASEAN's designated Transit Transport Routes (TTRs) in Lao PDR and Myanmar. The implementation of Singapore-Kunming Rail Link (SKRL) sections from Singapore to Phnom Penh are on schedule. The GoI should identify the importance of this project as the SKRL project in the north part also has been identified with funding issue that leads to missing links largely in Thailand and Cambodia, Thailand and Myanmar, and between Cambodia and Vietnam. Currently, the project is only operated in Singapore, Malaysia, and Thailand (Chin, 2012).

The establishment of the ASEAN Broadband Corridor $(A B C)$ has been completed following the ASEAN ICT Masterplan 2015 MidTerm Review. ASEAN Member States (AMS) is currently deploying one or more highspeed national broadband network backbone beyond 2015. The West KalimantanSarawak power interconnection project is expected to be commercially operational in 2015 , but the implementation of other energy interconnection projects under the ASEAN Power Grid and the Trans-ASEAN Gas Pipelines face delays due to resource constraints, lack of commercial viability of the projects, challenging terrain, and technical challenges.

Institutional Connectivity: While efforts to operationalise the three transport facilitation agreements of ASEAN Framework Agreement on the Facilitation of Goods in Transit (AFAFGIT), ASEAN Framework Agreement on the Facilitation on Inter-State Transport (AFAFIST) and ASEAN Framework Agreement on Multimodal Transport (AFAMT) are currently ongoing, completion of the relevant protocols to AFAFGIT and the ratification of agreements and their protocols remain pending. Both the Air Transport Economic Cooperation Work Plan (2014-2015) and Air Transport Technical Cooperation Work Plan (2014-2015) were adopted to further facilitate the establishment of the ASEAN Single Aviation Market (ASAM). The Implementation Framework of the ASEAN Single Shipping Market including its Action Plan is expected to be developed by 2015. Trade facilitative measures are being undertaken to achieve free flow of goods and services. The ASEAN Trade Repository / National Trade Repositories (NTRs) are expected to be in place by 2015 .

The ASEAN Policy Guidelines on Standards, Technical Regulations and Conformity Assessment Procedures (STRACAP) and the ASEAN Policy Guidelines on Accreditation and Conformity Assessment are expected to be adopted by 2015 . The exchange of ASEAN Trade in Goods Agreement (ATIGA) Form D and ASEAN Customs Declaration Document under the scaled-down version of the ASEAN Single Window (ASW) Pilot Project was successfully conducted by 7 participating 
Member States (The 7 participating Member States are Brunei Darussalam, Indonesia, Malaysia, the Philippines, Singapore, Thailand, and Vietnam). The Protocol on the Legal Framework to Implement the ASW that would govern cross-border data exchange among AMS for "live" implementation would be completed by 2015. Most of the work on the enhancement of border management capabilities is being done at the sub-regional and bilateral levels while efforts at the ASEAN level require further acceleration.

People-to-People Connectivity: This pillar enhances development through promoting deeper intra-ASEAN social and cultural understanding. A few plans are The ASEAN Curriculum Sourcebook (for primary and secondary schools) was developed in 2012, and ASEAN is now promoting utilization of the Sourcebook, in addition to the existing supplementary materials on ASEAN studies in schools. The ASEAN Studies Course is being implemented under the ASEAN University Network for undergraduate students to further promote the study of ASEAN among youths. The development of the ASEAN Virtual Learning Resources Centre (AVLRC) is progressing well with the first phase, focusing on ASEAN's peoples, culture, history, places of interest, education, youth and ICT, expected to be completed by 2015 .

The main obstacle of MPAC is the sustainable source of funding and good governance has been identified to be crucial in the current state by Das (2013). The paper highlights both issues will be important to support the building of ASEAN Community as the integration would lead to the increasing volume of goods, services, people and information across the region. The projects in the MPAC clearly required a large amount of funding and continuous flow of capital. To address this, the ASEAN has established the ASEAN Infrastructure Fund (AIF) that commenced in 2012. The fund initial capital was of US\$ 485.2 million, with contributors from AMS (US\$ 335.2), ADB (US\$150) and hybrid capital (US\$162). However, there were concerns that AIF may not be utilized optimally due to unclear institutional setup and the amount may not be sufficient enough to finance infrastructure development plans. Beside ADB, the World Bank also supports the implementation of MPAC through a numerous study such as the join study between ASEAN Secretariat and World Bank that offers the alternative budget mechanism through the PPP. However, there is no project has been implemented under this scheme. There are 5 MPAC projects in Indonesia that are recommended under the PPP scheme as suggested by the World Bank (World Bank, 2015).

Another issue in the ASEAN is the limited capability in planning at the regional level and the cross-border projects, as most developments in this level are conducted by multilateral development institutions (Abidin and Rosli, 2013, p. 157). The lack of experience is also coupled with the complexity of the cross-border projects as it is usually large, require long-term payback periods, high risk of revenue due to pricing and currency fluctuation, and prone to environmental and societal impact. The overlapping projects will also cause non-optimal use of resources, thus national development plans, which usually preceded regional development, have to correspond and fit with regional vision.

Thus, national planning and regulatory among AMS is important to avoid duplication and conflicting systems, efficiently and effectively promote economic growth, and transparency and consultation process between national and regional infrastructure plans. This shows the importance of coordination to minimise investment to achieve regional infrastructure standard and quality. For instance, ASEAN could support AMS road development by linking missing parts of national road system and harmonize the various infrastructure standards into a regional one. The latter would ensure flow of movement of vehicles, people, goods and services (Abidin and Rosli, 2013, p. 160). The study by Warsilan and Noor (2015) shows that road construction in the Kalimantan City of Samarinda is significant for economic growth and reduces poverty as it accelerates trade and economic activities.

Despite promising development due to the rapid number of protocol that has been ratified in the institutional and people-topeople agreements, the implementation will need time. These agreements are crucial and important to ensure the trade facilitation and infrastructure development. The final report by ADB (2016) highlights the persistent of ASEAN Way governance that plays important role in shaping ASEAN activities. As the noninterference principles including economic and political policies, ASEAN Way would limit the ASEAN Blueprints implementation if the blueprint plans are not align with the national interest. For instance, the limited 
collaboration between Indonesia and the Philippines has extended the negotiation on RORO transportation and trade facilitation. Thus, ASEAN Way has been criticized to hinder and slow-down the process of economic integration (Masilamani and Peterson, 2015).

As a result of the ASEAN Way, program and project implementation in ASEAN are unwilling to point out party that should be blamed for. For instance, Kartika and Atje (2013) argues that the AEC scorecard became unclear and not informative due to its vague report that does not blame any party on the lack of progress on implemented measures in AEC. The paper also highlights the lack of available recent data on exclusion list of each AMS, tariffs and non-tariff barriers. Another impact is the slow progress of institutional connectivity with measures under trade facilitation including customs modernization, standards, services liberalization, investment, and ratification of transport agreements. This shortfall is due to the delay in ratification of signed ASEAN agreements and its protocols. This reflects two issues in the institutional of ASEAN; first, the issue shows the poor conveyance of regional commitments into national policies that may suggest lack of policy-making capacities and poor political will to achieve regional plans. Second, the importance of the mechanism to monitor, identify issues and address implementation gaps among AMS. Third, the need of stronger institutional capacity of ASEAN to enforce rules and monitor the progress of integration (Rillo, 2013).

\section{ASEAN Connectivity Projects in Indonesia}

This section provides synchronization analysis between the MPAC and RPJMN 20152019. However, as the MPAC projects detail in both location and type of project, there are several projects that are not directly found in the RPJMN. The following discussion elaborates the activity. The MPAC projects are mainly related to the following program in RPJMN:

The Construction of national connectivity to achieve a balance development program with the following MPAC projects such as upgrade all "below Class III" sections of AHN into at least "Class III", (1) Upgrade all "below Class III" sections of AHN into at least "Class III," (2) Construction of High Grade Highway in Sumatra, (3) Construction of Kuala Tanjung and Bitung ports, (4) Enhance capacity of
24 ports (5 hub ports and 19 feeder ports) to accelerate Sea Toll, (5) Construction and development of 163 non-commercial ports as Sea Toll sub feeders, (6) The study by JICAASEAN suggesting three routes for ASEAN RORO development in Indonesia (2013), (7) In order to support Sea Toll logistic terminal and priority zones, there will be a Presidential Decree to establish Land Banking Institution, (8) Railway construction in Java, Sumatra, Kalimantan, Sulawesi, and Papua to strengthen national connectivity and integrate with Sea Toll to enhance competitiveness, and (9) National transportation provision through transportation industry empowerment including N-219 plane development and shipping industry, locomotive, railway and busses.

The Effective and efficient improvement in infrastructure financing program relates to the following MPAC projects: (1) Provide financing support to achieve infrastructure development through alternative funding scheme such as PPP, the establishment of development bank, and other innovative financing schemes, (2) Accelerate access for broadband development, and (3) Develop broadband infrastructure in bordering regions.

The Energy Sovereignty program relates to the following MPAC projects: (1) Expand gas pipeline and LNG terminals development by the government, State-Owned Enterprises (SOE), and private with prioritizing national interest in investment centres and distribution network, and (2) Energy Storage System (ESS) Construction to support electricity system and smart grid expansion

Projects that are related to national development vision from the Peripheral includes the ASEAN RORO Projects (Dumai and Bitung ports), Dry port project (Entikong dan Nanggabadau in West Kalimantan), FS connectivity between archipelagic AMS and mainland ASEAN, Trans-ASEAN Gas Pipeline (TAGP) projects in Gresik dan Natuna, Power grid projects in Kalimantan Barat (Bengkayang) dan Sumatra, establish an ASEAN Broadband Corridor in regencies and cities, and prioritize and expedite roll-out of broadband Internet capable infrastructure to schools in regencies.

\section{Constrains and Its Impact}

Despite the promising development, there are few constraints found in implementing MPAC physical infrastructure projects and 
institutional connectivity: Resources Issues as the lack of budget from ASEAN and limited budget of the line Ministries. There are MPAC projects that differ and not harmonized with national development plan (RPJMN). As a result, some MPAC project in Indonesia is lack of and without a budget. It is lack of physical project constructions that require a large sum of funding. The ASEAN Secretariat and ACCC have proposed the use of PPP scheme. However, it remains as a discussion topic. The limited communication and collaboration between AMS and AMS with ASEAN Secretariat causes institutional issues that constrain the physical infrastructure project development. For instance, the import regulation that applies to vehicles crossing the border causes issues to accelerate RoRo development.

There is a need for inter-agency coordination that includes the responsibilities and commitments of participating administrations. This should also share information on project agenda and budget. For instance, the issues in public work projects include land acquisition, environmental aspects such as forestry and environment impact assessment, and the budget guarantee for multi-year road construction. Another issue happens within the Ministry of Transportation: there is no single division responsible for Multcapital Transport issues, so it has to be handled cross divisions.

In addition, coordination between AMS governments is also important to ensure progress on project implementation at each AMS. Regulation - Project agenda and budget between MPAC and National Development should be harmonized. The MPAC 2009-2015 projects are detailed that hinder Indonesia's flexibility to implement projects if it is not included in the national development agenda. The Importance to understand how ASEAN Works - The GoI should find a way to accelerate MPAC implementation despite ASEAN Way and principles that may hinder its progress.

The impacts of the constraints are as follows (i) hinder physical infrastructure construction in telecommunication and maritime sector and single market implementation which causing Indonesia's lag development in these sectors. Thus, this will hinder Indonesia's potential to implement MPAC projects if it is not included in the national development agenda, such as the RORO project and the Toll Sea development concept, and to implement cross-border transportation that challenges people and goods movement within ASEAN. In Indonesia, the RORO should be integrated with the Sea Toll project that is the main project in the current government. The RORO could be a feeder for people and goods movement for the Sea Toll. Related to Sea Toll, the main issue in Indonesia sea transportation is professionalism and individual competencies of human resources, national sea vehicles, and logistic capacities (Malisan, 2013). These constrain would hamper the "Development from the peripheral regions" concept, a concept scheme under the new GoI as lack of telecommunication and maritime infrastructure.

On the other hand, the impact of the elimination of non-tariff barriers to Indonesian market potentially increases import products to have a lower price than domestic ones and poor infrastructure from the hinterland. In the long run, this would harm the local economy. Additionally, by combining elimination of trade barriers with spatial proximity, for example between Indonesia and the Philippines, RORO would also pressure local economy. This is crucial as it will be challenging for Indonesia to enter the ASEAN integrated market in 2015 , as with abundance population, lack of infrastructure and institutional problems, Indonesia would be a potential market destination for AMS products. Furthermore, the lack of negotiation results to develop procedures of border management (Customs, Immigration, Quarantine/CIQs) would be a problem to manage the cross-border movement of passengers and goods. Thus, it hinders good governance in ASEAN market integration.

\section{The Riau Corridor: A Case Study}

In this section, three case studies on potential and issue of MPAC implementation are discussed. The three case studies highlight the importance of the MPAC projects on the regions. The case studies are an integrated development in the Riau corridor as part of the Dumai-Malacca corridor. The value added for the project can comprise the creation of a bonded transport process (road and rail), to streamline documentation and processing time for goods between Indonesia and Malaysia (a principle of MPAC), specific and streamlined documentation and processes, to facilitate buses and vehicle movement between ports, and creation of increased capacity for the movement of goods and 
services. On the other hand, the corridor provides access to AHN and the SKRL without locking into Singapore as the connectivity point.

This paper observes the Malaka-Dumai corridor as both ASEAN's flagship transport infrastructure projects, the AHN and SKRL, are found here and the high potential of the RORO. The AHN and RORO projects are under construction with guaranteed budgets from the Ministry of Public Works and the Ministry of Transportation respectively. At the regional level, Indonesia has ratified all protocols in transport, except for the SKRL because there is currently no physical connection. Furthermore, there is synchronization between physical projects such as in Malaka-Dumai Economic Corridor Multimodal Transport with the toll road.

The analysis compromised through synchronization and reviewing formal documents of ASEAN at national and local levels such as MPAC and RPJMs for each study cases. In addition, other formal documents used including local government working plan and strategic plans by local government agencies.

\section{RORO facilities}

In this corridor, there is also a plan to develop an RO-RO service that can benefit businesses and the local economies by increasing trade, business, investment and tourism across the route (JICA, 2013). Furthermore, the study also emphasizes that the State of Malacca prioritizes tourism development through RO-RO shipping rather than freight trade, which correspond to the development of this corridor. Among potential users of this route is supporter of RO-RO that can complement existing air and ship passenger services that can attract certain travel market segments such as traders, overseas workers, and medical tourists (JICA, 2013). Malacca residents may utilize the new route to go shopping on weekends with their own cars, both for personal consumption and commerce. In addition to the passenger, there are interests from cargo stakeholders and tour operators to use the RO-RO service. Hence, these economic activities could accelerate a region-wide development in this corridor.

The JICA (2013) study shows that the international RO-RO terminal is planned at Pangkalan Sesai, Dumai City where the domestic RO-RO terminal was constructed to provide RO-RO service connection with Rupat Island. The area is becoming a popular shipping terminal area since DGST constructed another jetty for domestic and international passenger ferries to be relocated from the existing passenger terminal in the Port of Dumai. To accommodate an international RORO vessel, passenger and vehicle terminals will have to be constructed in addition to the existing facilities with total cost estimated at US\$1.3 million. All infrastructure development in Dumai is completed and ready for the route operationalization. The Malaysian company, Lestari Indomar Bahari is ready to serve 5 calls/day, while RoRo terminal in Dumai and Malacca will be ready in 2018. For land transportation, the development of the dry port is included in the President Instruction No. 6/2015 to accelerate bordering regions and it is currently under construction.

\section{Expressway Pekanbaru to Dumai}

The Dumai - Pekanbaru road is a part of the Trans-Sumatra road which is designated as ASEAN Highway No.25 as well as Transit Transport Route (TTR). Presently, the GoI is constructing and upgrading the Sumatra highway as part of the AHN. However, the GoI argues that the Sumatra highway will not meet the AHN standard as a class II since the Ministry of Public Works expects that the user volume of the highway does not require a higher class road. The Dumai-Pekanbaru road is part of the Trans-Sumatra road and designated as AHN 25 in Sumatra which has met the class 2 AHN. Despite they are aware of $\mathrm{AH}$ obligations under MPAC, as the traffic is very low, there is no use to improve the $\mathrm{AH}$ to class 1 . Overall, the project has already achieved the target. The Government of Indonesia has the plan and construct the road for a few years, and it was included in the Master Plan for Acceleration and Expansion of Indonesia's Economic Development' (MP3EI). Now the toll road project which included in the RPJMN 2015-2019 (135 km) is ongoing in parallel with the existing road $(199 \mathrm{~km})$. The toll road will reduce the current travel time (5-6 hours) to only one third.

The above two infrastructures of RoRo and expressway highlighted the importance of Dumai city as an emerging new growth center in the province. The city is the highest contributor to the manufacturing and oil industries for Riau province. Furthermore, Alhempi et al. (2014) suggest that Dumai city could also function as a hub and transshipment center for manufacturing products from its neighboring districts, Rokan Hilir and Bengkalis regencies. 


\section{Rail Connectivity and other Projects}

Under the Mid Term Plan (RPJMN), the GoI envisions to extend the SKRL rail link in Sumatra, through Dumai and across Java to Surabaya. The construction has commenced in 2015 for connection between Rantauprapat, the last station in Northern Sumatera railway to Duri-Dumai in Pekanbaru Province. This cross-border rail link will connect Indonesia with mainland ASEAN, China and India. The railway projects in RPJMN are in line with expected SKRL that will be completed in 2020.

Another project is the expressway between Pekanbaru and Dumai (new development Pekanbaru - Kandis 90 Km (EIA), rehabilitation of Kandis-Duri $20 \mathrm{~km}$ (SID), and Duri-Dumai $63 \mathrm{Km}$ (SID). The expressway is planned for $107 \mathrm{~km}$ with 300 passengers and 150 tons traffic and it is expected to reduce the current travel time (5-6 hours) to only one third (JICA, 2013). Currently, the BPJT has purchase $25 \mathrm{~km}$ of ROW and there are plans for more ROW acquisition. Expressway is planned for completion in 2025. There is also another important project that may accelerate the development of the corridor, that is the Batam Island Expressway. The land is made ready by the Batam Authority and the President Regulation 100/2014 supports the construction. The FS by ADB is completed and currently under review by Batam Authority. The land already purchased by the Batam Authority Supported by the President Regulation 100/2014 on the acceleration of 4 highway construction in Sumatra. The project value approximately about IDR3 billion, however, the estimated and secured budget remain undisclosed. These expressways would improve economic and trade connectivity between both regions. Finally, another low profile development plan is the Malacca strait bridge from Dumai. Presently, the development plan remains as a feasibility study (Lestari, 2015).

\section{Conclusions}

This paper has presented the issues and potential of ASEAN Connectivity implementation in Indonesia. There are a few findings from this paper, which are the lack of MPAC implementation at both ASEAN and Indonesia levels. At the ASEAN level, the association lacks a designated authority and leadership to carry MPAC forward in the member countries. This lack of institutional support linked closely to the political and institutional relationship that ASEAN stands for. It is known as the ASEAN Way (Nesadurai, 2003). In this sense, the loose governance system under which the ASEAN operates emphasizes the commitment of member countries. This problem is complicated by the diversity of economic development that leads to variation of capacity and international competitiveness of the logistics sector. Hence, the logistics policies and regulations are difficult to harmonize in the context of liberalization, as suggested by Tongzon (2011, p.26).

Second, the fact that the ASEAN Connectivity policy is not equipped with additional and appropriate funding from ASEAN has curtailed the implementation of the project in the AMS and requires the ASEAN as an association to integrate programs and projects that have similar targets. For instance, the MPAC could be integrated with the proposed establishment of ASEAN Infrastructure Financing Mechanisms (AIFM). Both programs share two critical aims; accelerating the infrastructure development to promote regional economic growth and prosperity, and strengthening intraregional links and dynamics growth with a view to accelerate the realization of the ASEAN Economic Community 2015 vision (Bhattacharyay, 2009).

Third, at the state level, Indonesia has no institution to lead the MPAC delivery. The presence of such institution is critical to define and coordinate strategic projects with higher value added. Surveys of public and private stakeholders suggest the lack of leading in the national agency to coordinate and direct national development programs that link with the ASEAN Connectivity. Fourth, the survey to national ministries and private companies regarding ASEAN Connectivity suggest the lack of knowledge about the existence of MPAC and how it may promote integrated supply chain in ASEAN. However, it should also be noted the lack of knowledge on supply chain management as surveyed by Tongzon and Cheong (2014).

Finally, the potential economic and welfare benefit from ASEAN Connectivity could only be achieved through national policies to accommodate projects into the national development plan. Hence, the national plan could integrate with regionalwide connectivity with ASEAN. As Coe (2014) who argues that physical logistics infrastructures will become less important has 
proved unfounded and remains to be the main dimension of regional integration.

\section{Acknowledgement}

This paper builds up on a preliminary report study initiated by the Asian Development Bank (ADB) project titled "Support for Selected Sector Analysis for National MediumTerm Development Planning 2015-2019 on ASEAN Connectivity" TA-8535 INO.

\section{References}

Abidin, M.Z., and Rosli, F., (2013). Infrastructure Development in ASEAN, in Sanchita Basu Das, ASEAN Economic Community Scorecard: Performance and Perception. Singapore: ISEAS Publishing

Alhempi, R.R., Zainal, H., and Kusumastuti, S.Y. (2014). Keterkaitan Sektor-Sektor Ekonomi Potensial di Provinsi Riau. Jurnal Mimbar 30(1) pp.62-71

ADB, (2016), Support for Selected Sector Analysis for National Medium-Term Development Planning 2015-2019 on ASEAN Connectivity, Final Report ADB TA-8535 INO

ASEAN Secretariat, (2010), Master Plan on ASEAN Connectivity

ASEAN Secretariat, (2015), ASEAN Assessment Of MPAC Implementation, The 1/2015 ASEAN Connectivity Coordinating Committee (ACCC) Meeting, 5-6 March 2015.

ASEAN Secretariat, (2015), Key Outcomes And Follow-Up Matrix Relating To ASEAN Connectivity For ASEAN Summits And Related Summits, The 1/2015 ASEAN Connectivity Coordinating Committee (ACCC) Meeting, 5-6 March 2015

ASEAN Connectivity Coordinating Committee, Summary assessment of MPAC implementation as per February 26th 2015.

Bhattacharyay, B. N. (2009). Infrastructure Development for ASEAN Economic Integration. ADBI Working Paper 138. Tokyo: Asian Development Bank Institute

Chin, A.T.H., (2012), ASEAN Transport Policy, Infrastructure Development and Trade Facilitation. In Yap Kioe Sheng and Moe Thuzar (Eds): Urbanisation in Southeast Asia: Issues and Impacts. ISEAS: Singapore.

Coe, N.M., (2014). Missing links: Logistics, governance and upgrading in a shifting global economy, Review of International
Political Economy, 21:1, 224-256

Das, S.B. (2013)., Understanding the MPAC, in Sanchita Basu Das, Enhancing ASEAN's Connectivity, Singapore: ISEAS Publishing

JICA-ASEAN, (2013), The Master Plan and Feasibility Study on the Establishment of an ASEAN Roll-On/Roll-Of (RO-RO) Shipping Network and Short Sea Shipping

Kartika, P., and Atje, R., (2013). Towards AEC 2015: Free Flow of Goods within ASEAN, in Sanchita Basu Das, ASEAN Economic Community Scorecard: Performance and Perception. Singapore: ISEAS Publishing

Lestari, E., (2015). Konektivitas Jasa Logistik di Indonesia Menuju Pasar Tunggal ASEAN in Zamroni Salim, Kesiapan Indonesia Menuju Pasar Tunggal ASEAN dan Basis Produksi ASEAN: Sektor Jasa Logistik. LIPI: Jakarta

Malisan, J., (2013). Analisis Kesiapan Angkutan Laut dalam Pelaksanaan ASEAN Economic Community 2015 (STudi Kasus Makassar dan Bitung. Buletin Perhubungan, 25(6): 376- 387.

Masilamani, L., and Peterson, J. (2015). ASEAN's Constructive Engagement Policy, The Indonesian Quarterly, 43(1): pp. 2139.

Nesadurai, H.E.S., (2003). Attempting developmental regionalism through AFTA: The domestic sources of governance. Third World Quarterly, 24(2), p.235.

National Medium-Term Development Planning 2015-2019

Rillo, A.D., (2013). Monitoring the ASEAN Economic Community: Issues and Challenges, in Sanchita Basu Das, ASEAN Economic Community Scorecard: Performance and Perception. Singapore: ISEAS Publishing.

Tongzon, J., (2011). Liberalisation of logistics services: the case of ASEAN, International Journal of Logistics Research and Applications: A Leading Journal of Supply Chain Management, 14:1, 11-34.

Tongzon, J. and Cheong, I. (2014). The Challenges of Developing a Competitive Logistics Industry on ASEAN Countries, International Journal of Logistics: Research and Applications 17(4): pp.1-16.

Warsilan and Noor, A. (2015). Peranan Infrastruktur terhadap Pertumbuhan Ekonomi dan Implikasi pada Kebijakan Pembangunan di Kota Samarinda Jurnal Mimbar 31(2) pp.359-366.

World Bank, (2015, Enhancing ASEAN Connectivity Monitoring and Evaluation Project, The 1/2015 ASEAN Connectivity Coordinating Committee (ACCC) Meeting, 5-6 March 2015. 